Supporting Information

\title{
Convection-Induced Fingering Fronts in the Chlorite-Trithionate Reaction
}

Yang Liu ${ }^{\dagger}$, Wenxiu Zhou ${ }^{\dagger}$, Ting Zheng ${ }^{\dagger}$, Yuemin Zhao ${ }^{\dagger}$, Qingyu Gao ${ }^{*}{ }^{\dagger}$, Changwei Pan ${ }^{\dagger}$, Attila K Horváth ${ }^{*}$ ‡

${ }^{\dagger}$ College of Chemical Engineering, China University of Mining and Technology, Xuzhou 221116, People's Republic of China

${ }^{\ddagger}$ Department of Inorganic Chemistry ，University of Pécs , Ifjúság útja 6., H-7624 Pécs, Hungary

*To whom correspondence should be addressed.

Email: gaoqy@cumt.edu.cn

Email: horvatha@gamma.ttk.pte.hu 

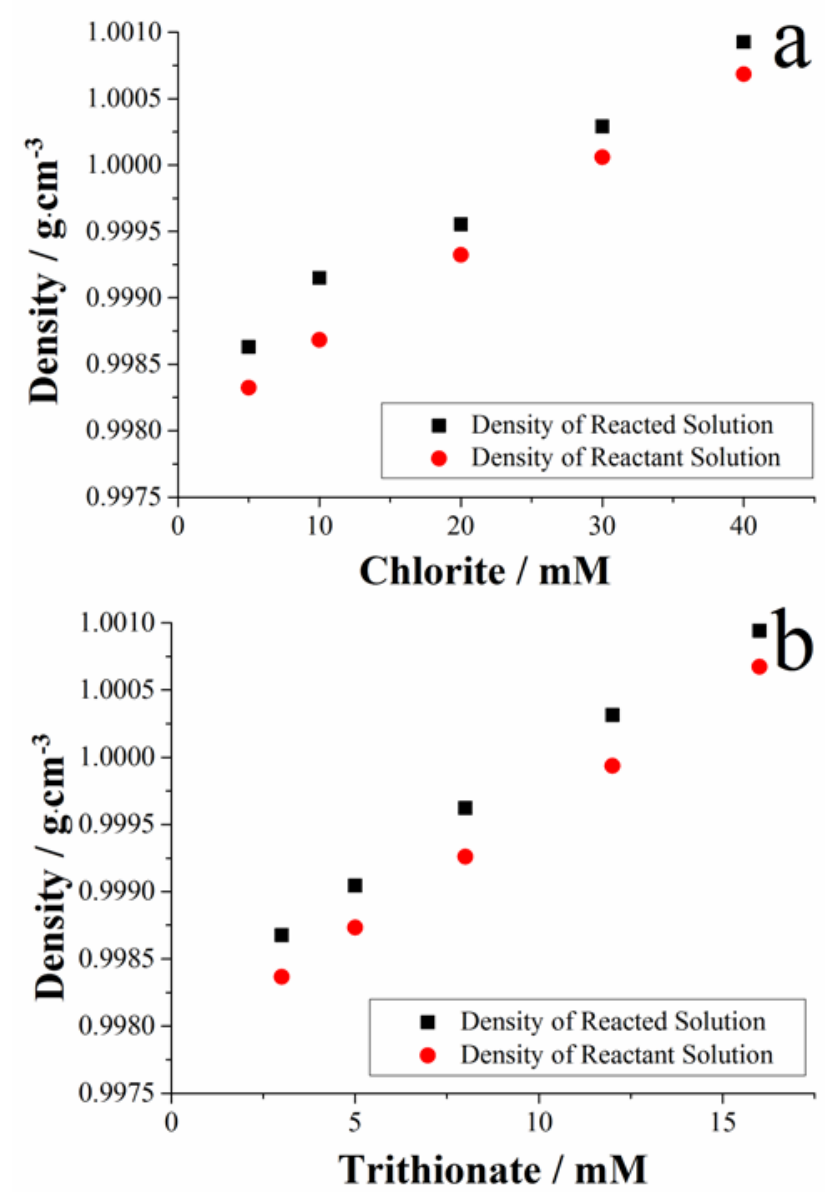

Figure S1. The density of the reactant and the reacted solution at different concentration combinations. The initial concentrations of reactant were fixed at $\left[\mathrm{S}_{3} \mathrm{O}_{6}{ }^{2-}\right]_{0}=5 \mathrm{mM}$ and $\left[\mathrm{OH}^{-}\right]_{0}=1 \mathrm{mM}(\mathrm{a})$, and $\left[\mathrm{ClO}_{2}^{-}\right]_{0}=11 \mathrm{mM},\left[\mathrm{OH}^{-}\right]_{0}=1 \mathrm{mM}(\mathrm{b}) . \mathrm{T}=25^{\circ} \mathrm{C}$.

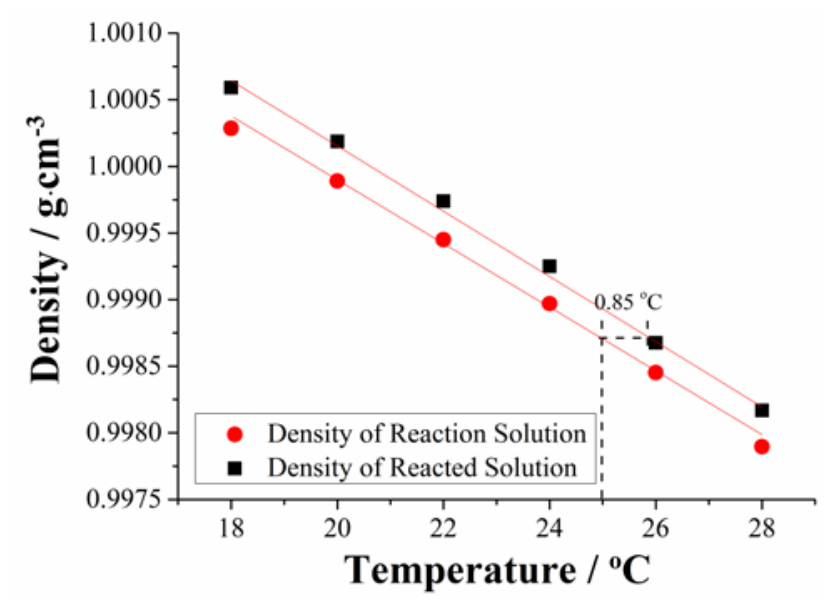

Figure S2. Effect of temperature on the density of the reactant and the reacted solution. The initial concentrations of reactant were fixed at $\left[\mathrm{ClO}_{2}{ }^{-}\right]_{0}=11 \mathrm{mM},\left[\mathrm{S}_{3} \mathrm{O}_{6}{ }^{2-}\right]_{0}=5 \mathrm{mM}$ and $\left[\mathrm{OH}^{-}\right]_{0}=1 \mathrm{mM}$. 


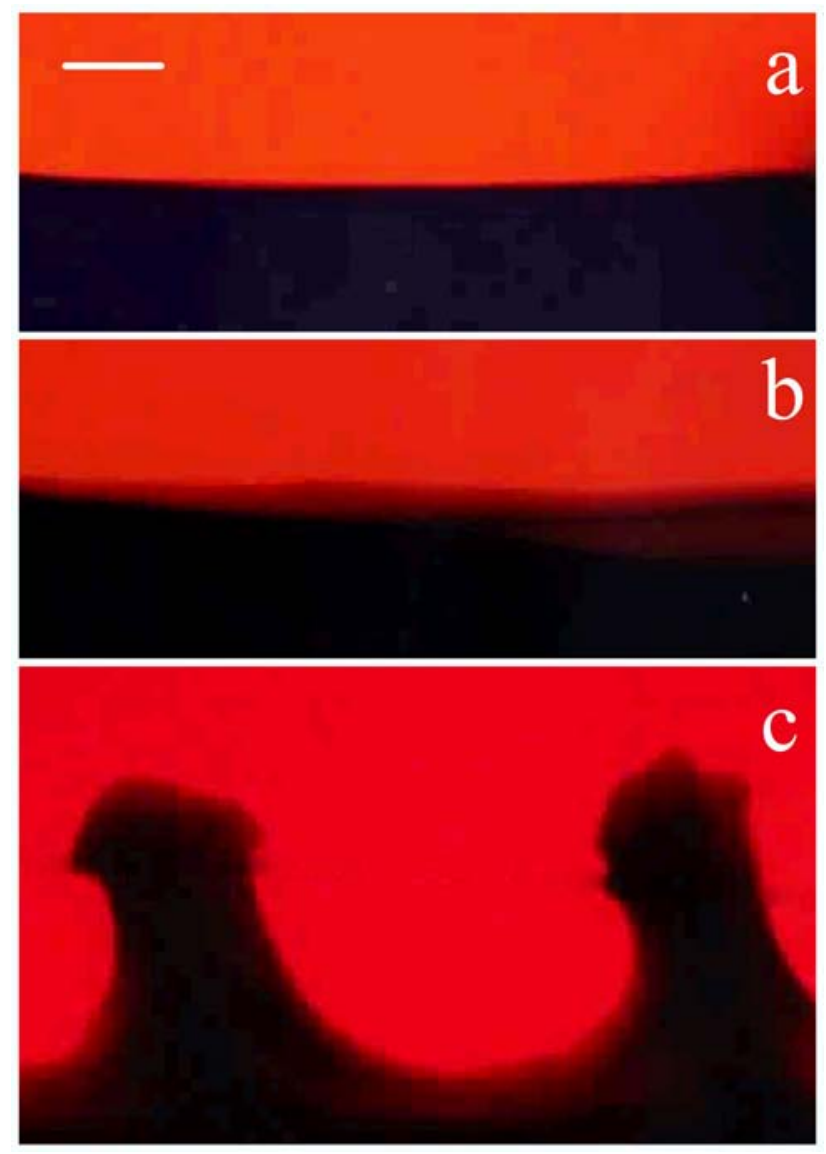

Figure S3. Effect of gap thickness on upward propagating fronts in the Hele-Shaw cell. The reactant concentrations were $\left[\mathrm{ClO}_{2}{ }^{-}\right]_{0}=11 \mathrm{mM},\left[\mathrm{S}_{3} \mathrm{O}_{6}{ }^{2-}\right]_{0}=5 \mathrm{mM}$ and $\left[\mathrm{OH}^{-}\right]_{0}=1 \mathrm{mM}$. The pictures were acquired with gap thickness of $3 \mathrm{~mm}$ (a), $4 \mathrm{~mm}$ (b) and $5 \mathrm{~mm}$ (c), respectively, at $60 \mathrm{~s}$ after front initiation. The scale bar in (a) was $5 \mathrm{~mm}$.

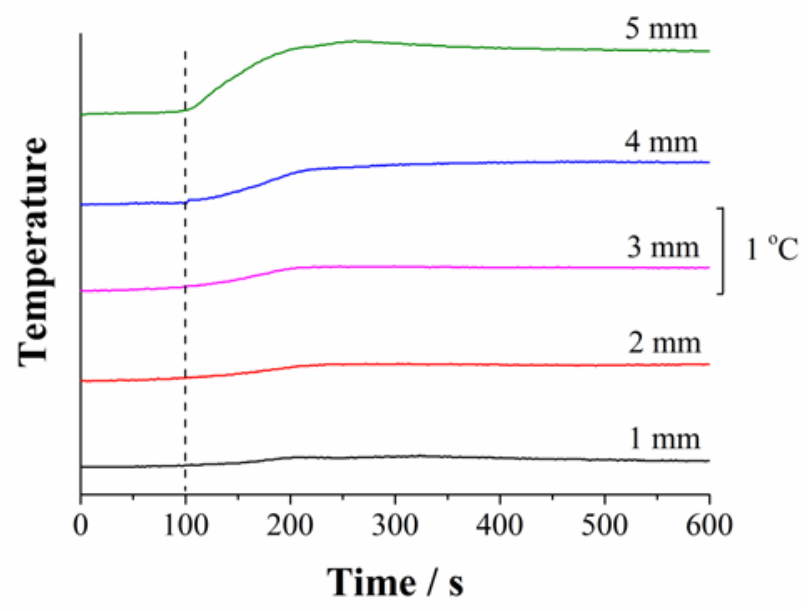

Figure S4. Temperature increment across the front at different gap thickness. The black, red, pink, blue and green lines correspond to the solution thickness of $1 \mathrm{~mm}, 2 \mathrm{~mm}, 3 \mathrm{~mm}, 4 \mathrm{~mm}$ and $5 \mathrm{~mm}$, respectively. Note that the initial temperatures were all maintained at $25.0 \pm 0.2{ }^{\circ} \mathrm{C}$ and the curves have been shifted for convenience. The fronts pass the detection point at about $100 \mathrm{~s}$ as the vertical dash line indicated. 

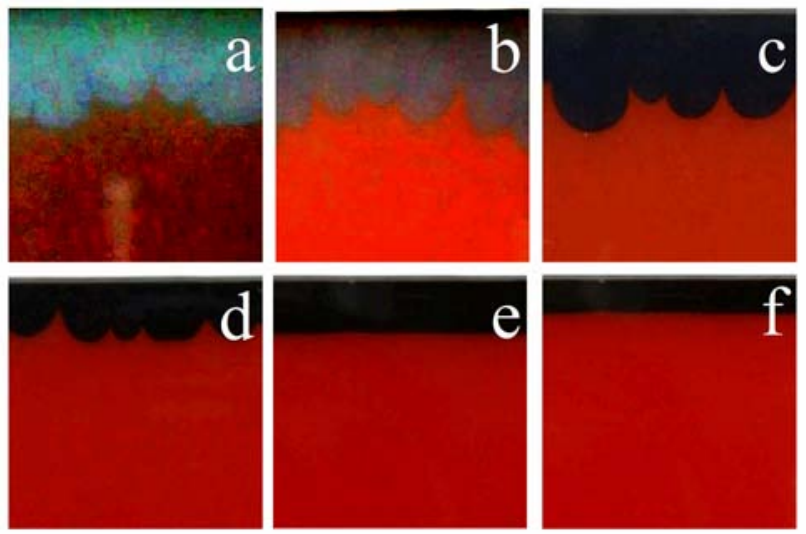

Figure S5. Fingering profiles for different concentration of indicator congo red. The reaction conditions were fixed at $\left[\mathrm{ClO}_{2}{ }^{-}\right]_{0}=11 \mathrm{mM},\left[\mathrm{S}_{3} \mathrm{O}_{6}{ }^{2-}\right]_{0}=5 \mathrm{mM}$ and $\left[\mathrm{OH}^{-}\right]_{0}=1 \mathrm{mM}$. The concentrations of congo red were $0.001 \%$ (a), $0.01 \%$ (b), $0.15 \%$ (c), $0.2 \%$ (d), $0.3 \%$ (e) and $0.5 \%$ (f) in mass. The gap thickness was maintained at $1 \mathrm{~mm}$. The pictures were obtained from the central section of the reactor at $240 \mathrm{~s}$ after front initiation, and the width was $30 \mathrm{~mm}$ in all cases. Note that (a) and (b) has been processed to enhance the contrast for convenience.

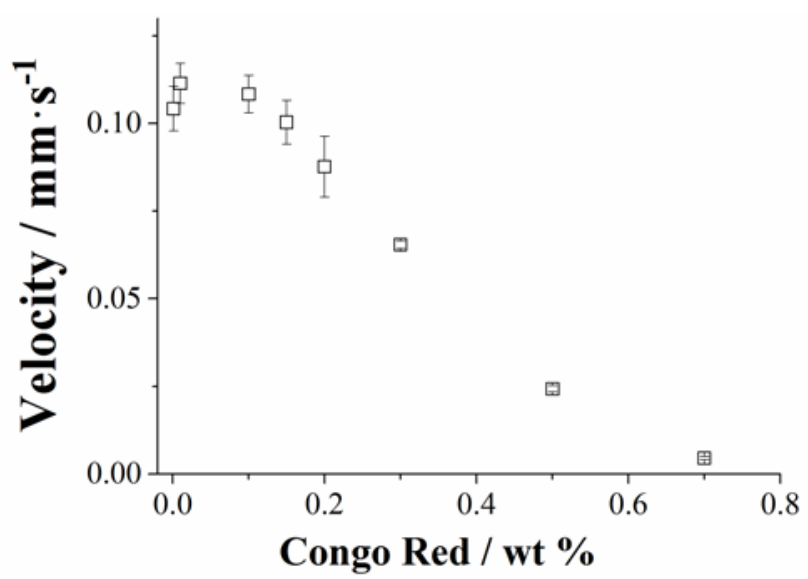

Figure S6. Front velocity for different concentration of congo red. The reactant concentrations were $\left[\mathrm{ClO}_{2}{ }^{-}\right]_{0}=11 \mathrm{mM},\left[\mathrm{S}_{3} \mathrm{O}_{6}{ }^{2-}\right]_{0}=5 \mathrm{mM}$ and $\left[\mathrm{OH}^{-}\right]_{0}=1 \mathrm{mM}$. Velocity was determined as the displacement of the vertex for the concentration of congo red less than or equal to $0.2 \%$ in mass, while with the planar front for more than $0.2 \%$ in mass. 